\title{
Pharmacognostic Characterization of Spondias mombin L. (Anacardiaceae)
}

\author{
Alex Lucena de Vasconcelos ${ }^{1}$, Alan Lucena de Vasconcelos ${ }^{2}$, Karina Perrelli Randau ${ }^{1 *}$
}

\section{Alex Lucena de Vasconcelos ${ }^{1}$, Alan Lucena de Vasconcelos ${ }^{2}$, Karina Perrelli Randau ${ }^{1 *}$}

'Departamento de Ciências Farmacêuticas, Universidade Federal de Pernambuco, Avenida Professor Arthur de Sá, Cidade Universitária, Recife, Brasil. ${ }^{2}$ Faculdade Estácio do Recife, Av. Engenheiro Abdias de Carvalho, No 1678, Bongi, Recife, Brasil.

\section{Correspondence}

Karina Perrelli Randau, Programa de Pós graduação em Inovação Terapêutica, Laboratório de Farmacognosia, Departamento de Ciências Farmacêuticas, Universidade Federal de Pernambuco, Avenida Professor Arthur de Sá, Cidade Universitária, Recife, BRASIL.

Email: krandau@hotmail.com

DOI : 10.5530/pj.2016.6.1

Article Available online

http://www.phcogj.com/v8/i6

Copyright

(C) 2016 Phcog.Net. This is an open-access article distributed under the terms of the Creative Commons Attribution 4.0 International license.

\begin{abstract}
Background: Spondias mombin L. is fruit specie found in Tropical America and the coast of Africa, popularly known as cajazeira. Several researches with extract of leaflets show a diversity of promising pharmacological activities such as antibacterial activity, antiviral against dengue virus type 2, anti diabetic, among others. Objective: This paper aims to study the anatomical characteristics, phytochemical and histochemical from leaves of this species. Materials and Methods: Cross and paradermic sections from leaves were submitted to double staining with astra blue and safranin process for the anatomical study. Anatomical analysis of the structures was performed using an optical microscope. For ultra structure analysis, the leaf fragments, after processing and gold coating, were observed under scanning electron microscopy (SEM). The phytochemical analyses were performed using thin layer chromatography and the histochemical analyses using specific reagents for each metabolite group. Results: The leaf has anomocytic and tetracytic stomata distributed on abaxial surface. The midrib has convex symmetry with collateral vascular bundles in a closed arc disposition. The phytochemical showed the presence of mono and sesquiterpenes, triterpenes and steroids, hydrolysable tannins, phenylpropanoid glycosides, cinnamic derivatives and flavonoids. The histochemical tests allow us to state that phenolic compounds are found in the palisade parenchyma cells. Lignins can be found in woody vascular bundles and in perivascular sclerenchyma fibres. The volatile oils were evidenced in the schizogenous cavity, present in the parenchyma of the midrib. Conclusion: The results allowed characterizing anatomically the leaves of this species, outlining a profile of its phytochemical constituents and, in addition, determining which anatomical structures of storage of these metabolites by the plant.
\end{abstract}

Key words: Cajá, Anacardiaceae, Leaf anatomy, Histochemistry.

\section{INTRODUCTION}

The fruit species present considerable social and economic importance due to the nutritional character of its fruit, in addition to its use in traditional medicine. Different fruit trees of great economic importance for Brazil are within Anacardiaceae family. In Africa and South America are found 108 species restricted to these continents, ${ }^{1}$ while in Brazil, from 57 catalogued of this family, 14 of them are exclusive to this country. ${ }^{2}$ The Spondias genus has a history of use that dates back at least $6500 \mathrm{BC}$ in Tehuacan Valley, Mexico. ${ }^{3}$ Four species of Spondias are economically important in tropical America: S. dulcis, S. mombin, S. purpurea and S. tuberosa. ${ }^{4}$

Spondias mombin L. is a native fruit tree from tropical America having wide distribution and can be found throughout Latin America and parts of Asia and Africa. The tree can reach up to 25 meters high and has compound leaves with (sub) opposite leaflets. Its vernacular nomenclature may undergo a major change depending on the country. In Brazil, it may be called as taperebá, cajazeira-miúda, cajá-mirim or cajá. - $^{-7}$

Around 180 common names have been associated with Spondias purpurea, ${ }^{8}$ while 96 different common names have been described for S. mombin. ${ }^{10}$ In Mortom and Lim studies, ${ }^{9,10}$ Spondias purpurea and $S$. tuberosa have confusion in names.

The use of $S$. mombin is remarkable in both folk medicine and pharmaceutical industry. The aromatic and astringent bark is traditionally used for its emetic action, diarrhoea treatment, dysentery and haemorrhoids. In folk medicine, infusion of the leaves is used to treat bilious fevers, constipation and inflammation in the mouth, throat, stomach and genitals and also infectious conditions. ${ }^{7,11}$

Several studies with extract of leaves show a diversity of promising pharmacological activities, among them the antiviral activity against Coxsackie and Herpes simplex viruses; ${ }^{12}$ anthelmintic activity, ${ }^{13}$ antibacterial activity against strains of different spectra, confirmed in studies by Olugbuyiro et al: ${ }^{14}$ anti diabetic action, 
because of its agonist character of insulin receptors, ${ }^{15,16}$ activity against dengue virus type 2 , shown in experiments realized by Silva et $a l^{17}$ and leishmanicide activity. ${ }^{18}$

The extract from the leaves and branches present in its composition tannins, cinnamic derivatives, coumarins, saponins, terpenes and steroids, alkaloids and reducing sugars. ${ }^{19,20}$ Caraballo and colleagues, ${ }^{21}$ reported the presence of anthraquinones, flavonoids, naphthoquinones, sesquiterpenes, quassinoids and indole and quinoline alkaloids when analyzing $S$. mombin species, where these compounds can be related to medicinal activity.

For Budel et al.,22 the study of plants originates from the correct identification of the species and is one of the most important steps in any research to have reproducibility. Farias ${ }^{23}$ emphasizes the importance of the standardization of morphoanatomical markers for species, because such features become essential parameters for quality control of drugs and herbal medicines to be produced. Given the wide distribution of this species and the wide variety of uses and interests, whether traditional or scientific point of view, this paper aims to study the anatomical, phytochemical and histochemical characteristics of Spondias mombin leaves, native from Brazil.

\section{MATERIALS AND METHODS}

\section{Plant material}

Spondias mombin L. leaves were collected from species from Recife, Brazil, throughout October 2015. The voucher specimen was deposited in the Herbário Dárdano de Andrade Lima, at Empresa Pernambucana de Pesquisas Agropecuárias (IPA), for legitimation botany, under number 90666.

\section{Anatomical analysis}

Mature leaves of S. mombin were collected from up to five individuals for anatomical analysis. The samples were fixed in $\mathrm{FAA}_{50}{ }^{24}$ Cross and paradermic sections of the middle portion of the leaflets were freehand obtained, submitted to double staining process with astra blue and safranin $^{24,25}$ and mounted in glycerin on semi-permanent slides for the anatomical study. Analysis of the structures was performed using an optical microscope (Alltion). For scanning electron microscopy (SEM), leaf blades samples were fixed in an $2.5 \%$ glutaraldehyde solution (buffered with $0,1 \mathrm{M}$ sodium cacodylate) and post fixed in $2 \%$ osmium solution (buffered with $0,1 \mathrm{M}$ sodium cacodylate). Afterwards, material was critical-point dried through a graded ethanol series (Bal - Tec CPD 030). Suitable portions were mounted onto SEM stubs using doublesided adhesive tape and sputter-coated with gold (Leica EM SCD 500). Both adaxial and abaxial surfaces were examined with a QUANTA 200 FEG scanning electron microscope.

\section{Phytochemical prospection}

The methanolic extract from fresh leaves was processed by infusion $(0,1 \%)$ and subsequently analyzed by thin-layer chromatography (TLC) (Kieselgel 60, 0.2 mm, Merck), with different eluents systems and reagents to search alkaloids, mono- and sesquiterpenes, triterpenes and steroids, flavonoids, cinnamic derivatives and phenylpropanoid glycosides, hydrolyzable tannins and condensed tannins. Phytochemical screening of the extract was carried out using a conventional protocol. ${ }^{26,27}$

\section{Histochemical analysis}

Fresh mature leaves of $S$. mombin, without fixation, were collected from up to five individuals for histochemical analysis. Free hand cross sections from the middle portion of the leaflets were subjected to the following reagents/tests: Lugol reagent ${ }^{24}$ for starch, Sudan IV ${ }^{25}$ for detection of epicuticle wax, acid phloroglucin ${ }^{30}$ for lignins, potassium dichromate di $^{31}$ for phenolic compounds, hydrochloric acid for calcium oxalate crystals ${ }^{24}$
NADI reagent ${ }^{28}$ for essential oils and oil-resins, vanillin-hydrochloric $\operatorname{acid}^{32}$ for tannins and Dragendorff reagent ${ }^{29}$ for alkaloids. For each procedure employed on the samples, control samples, slides without any treatment (blanks), were also mounted. Observations and image documentation were performed with a light microscope (Alltion) equipped with a digital camera.

\section{RESULTS}

\section{Anatomical analysis}

The paradermic sections show an epidermis containing cells with thick walls, winding to polygonal contour, and those cells from the adaxial surface are more elongated and bigger than the abaxial surface ones (Figure 1A,B). The foliar limb is hypostomatic with anomocytic and tetracytic stomata randomly distributed along the abaxial surface (Figure 1B). The presence of simple and short unicellular trichomes can be seen in both adaxial and abaxial surfaces. Scanning electron microscopy images show the details of these structures (Figure 1C,D).

The cross section presents the epidermis covered with an epicuticular wax layer on both sides. The mesophyll is dorsiventral with two compact palisade layers of regular cells and relatively narrow, near the midrib. There is a tendency to form a monolayer of this parenchyma near the leaf margin. Several spongy parenchyma layers of loose elongated cells with little intercellular spaces form the abaxial surface of the mesophyll (Figure 1E).

The midrib has biconvex symmetry with collateral vascular bundles in a closed arc disposition. Two small groups of accessory vascular tissue can be found laterally to the central vascular bundle and higher up, composed of xylem and phloem surrounded by a sheath of sclerenchyma fibers (Figure 1F).

The angular chollenchyma is followed by perivascular sclerenchyma fibers, externally surrounding the xylem and phloem (Figure 1G). There is a presence of schizogenous secretory cavity in the parenchyma region, located near the phloem (Figure $1 \mathrm{H}$ ). The presence of idioblasts with druse-crystal forms is remarkable and are found throughout the mesophyll and midrib nearby the vascular bundles (Figure 1I).

The petiolule has convex symmetry with some undulations in a crosssectional view (Figure 1J). There are short to medium simple unicellular trichomes in both adaxial and abaxial surfaces. The epidermis has a thin cuticle that covers on both faces. A collenchymatous tissue anullar type can be seen after the epidermal monolayer, composed of short cells and slightly elongated axially. Crystalline inclusions of druses type are present with higher incidence in idioblasts located near the epidermis, on both sides. The crystals observed in petiolule are more numerous and have a greater diameter than observed in leaf blade (Figure 1K).

Vascular bundles with collateral arrangement in closed arc disposition are shown surrounded by a sclerenchymatous fiber layer. They are organized in small groups of vascular cylinders arranged concentrically. Schizogenous secretory cavities type are observed in phloematic vascular regions of each grouping, having one of the cavities with a greater diameter, located at the centre of the parenchymatous region (Figure 1L). Secretory cavity in medullary region has longitudinally elongated lumen. The lumen of the cavity is delimited by a secretory epidermis, composed of elongated cells of small dimension. A sheath is formed by two or three layers of flattened cells, arranged radially and externally the secretory epidermis (Figure 1M)

\section{Phytochemical prospection}

In the phytochemical prospection performed by TLC in leaves, mono- and sesquiterpenes, triterpenes and steroids, hydrolysable tannins, phenylpropanoid glycosides, cinnamic derivatives and flavonoids were found. The search for alkaloids and condensed tannins was negative. 

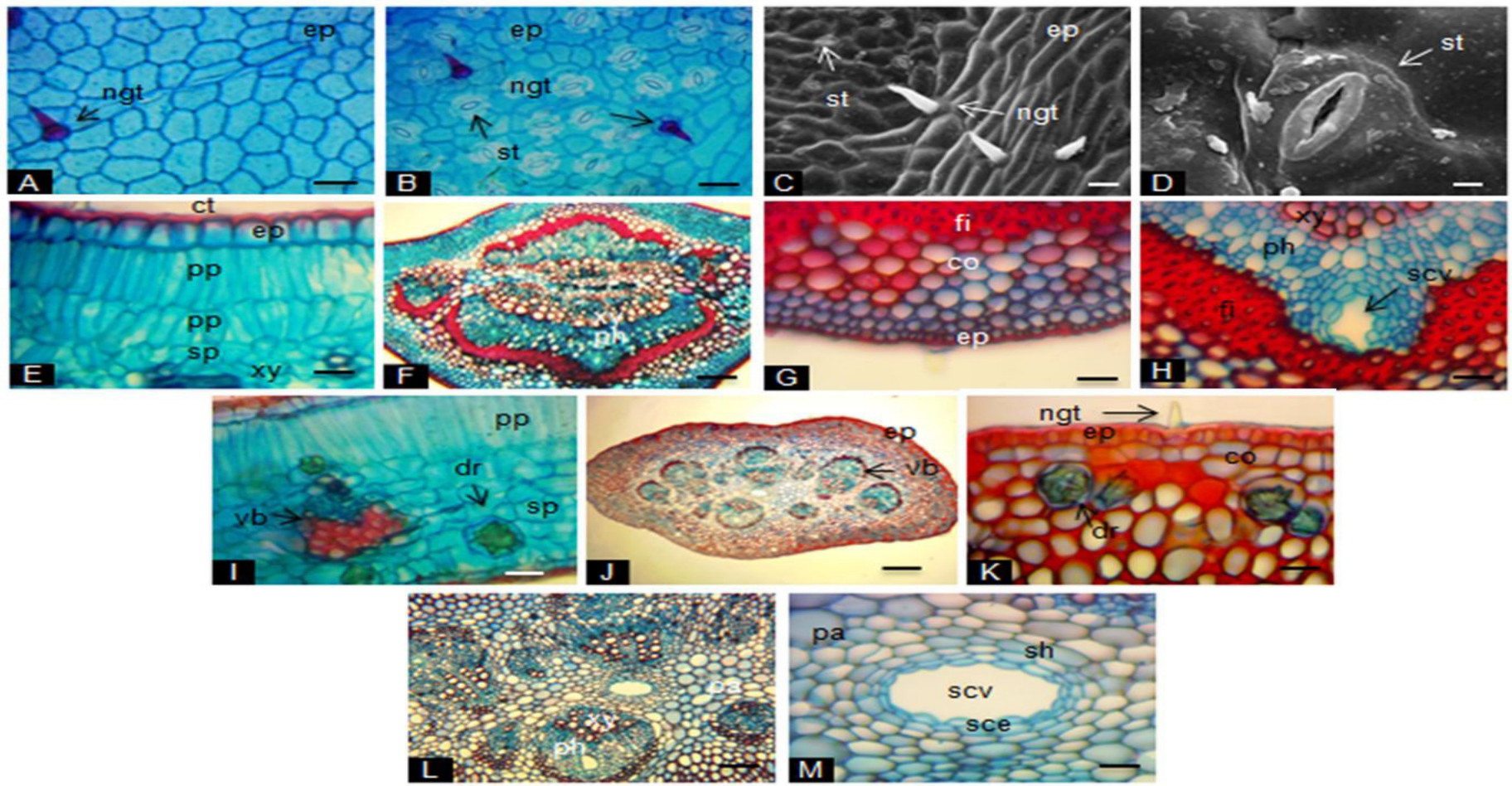

Figure 1 : Anatomical structures of Spondias mombin L. leaves.

Leaf: Paradermic sections: A. adaxial cells. B. abaxial cells. C, D. trichomes and stomata by SEM. Cross sections. E. palisade layer. F. midrib. G. sclerenchyma and chollenchyma. H. schizogenous secretory cavity. I. druse. Petiolule: J. biconvex symmetry. K collenchyma. L. collateral vascular bundles. M. schizogenous secretory cavity. ngt: non-glandular trichome, ct: cuticle, fi: fiber, co: collenchyma, , vb: vascular bundle, dr: druse, sce: secretory cell, sh: sheath. Bars: A, B,E,G,H,I,K,M: $25 \mu \mathrm{m}$. C,L,F: $100 \mu \mathrm{m}$. D: $10 \mu \mathrm{m}$.

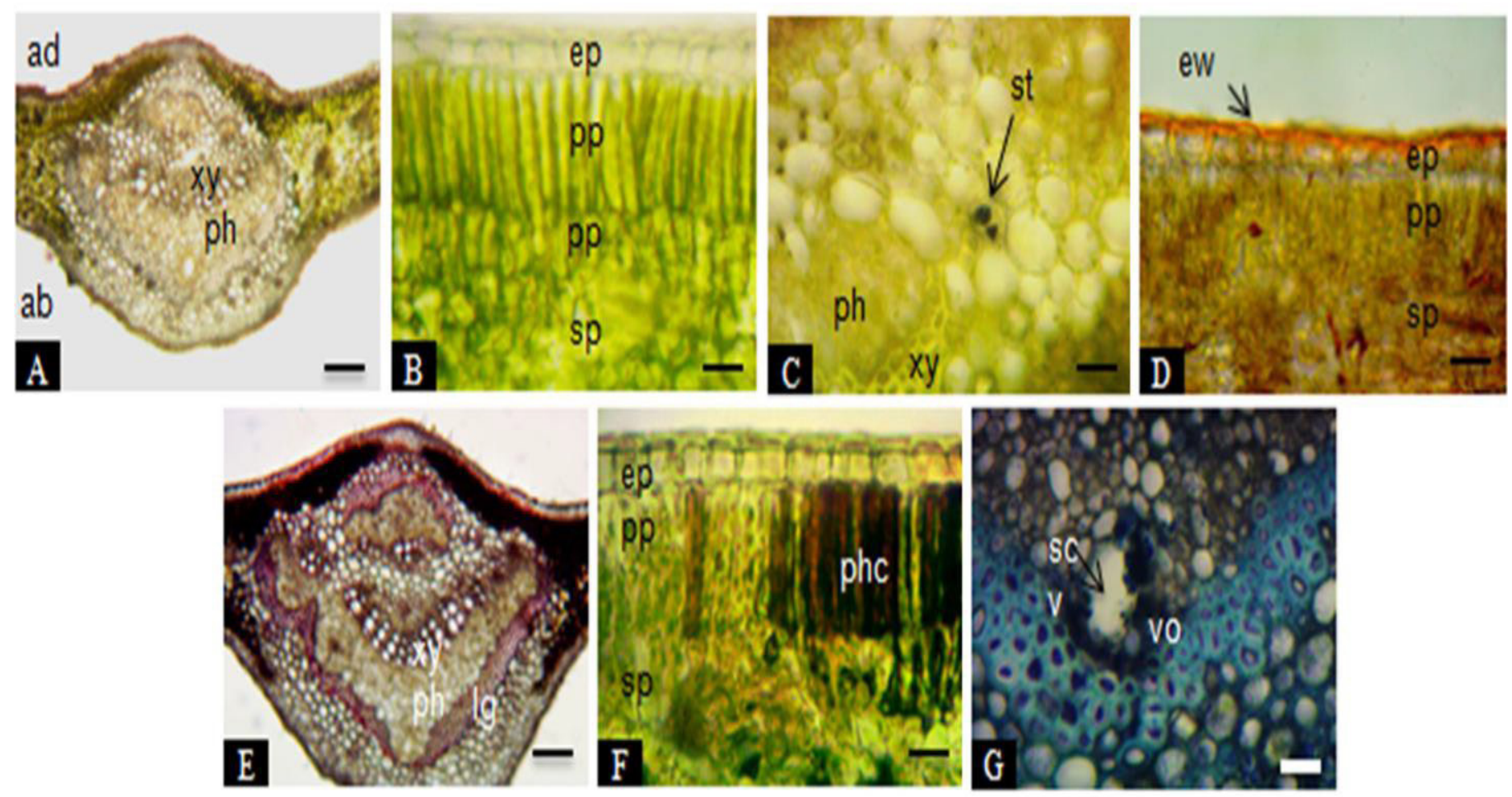

Figure 2 : Histolocalization of metabolites present in leaves of Spondias mombin L.

Control sample: A. midrib. B. mesophyll. Histochemical Tests: C. starch grains into idioblasts. D. epicuticular wax. E. lignins in sclerenchyma fibres. F. polyphenols in parenchyma cells. G. volatile oils inside secretory cavity. ad: adaxial, ab: abaxial, xy: xylem, ph: phloem, ep: epidermis, pp: palisade parenchyma, sp: spongy parenchyma, st: stomatum, ew: epicuticular wax, Ig:lignin, phc: phenolics compounds, scv: secretory cavity, vo: volatile oils. Bars: A, E. $100 \mu$ m. B,C,D,F,G. $25 \mu$ m. 
Vasconcelos, AL et al.: Pharmacognostic Characterization of Spondias mombin L.

\section{Histochemical analysis}

Histochemical analysis were performed comparing the control samples, cross sections of the midrib and mesophyll, with no chemical treatment (Figure 2A, B), with the sections after specific reagents. The tests show plant substances belonging to the primary metabolism, as the presence of starch granules within the parenchyma mesophyll cells (Figure 2C). After leaf treatment with Sudam IV it is observed the presence, on both sides, of a thin layer of epicuticular wax, with orange staining, constituting the protective cuticle (Figure 2D). The reaction with hydrochloric acid showed the soluble nature of the crystalline inclusions found, confirming the chemical composition of these calcium oxalate crystals. The presence of lignin can be verified by the pink structures stanning, not only in woody vascular bundles but also in the full extent of perivascular sclerenchyma fibres, both in the central vascular bundles, as accessories (Figure 2E).

The results of the phytochemical prospection served as support to direct the tests to histolocalization of compounds from plant secondary metabolism. Thus, the potassium dichromate tests, displayed the presence of phenolic compounds, distributed across the leaf, mainly in prismatic cells which compose the palisade parenchyma (Figure 2F). Leaf showed positive reactions to the NADI reagent, which blue stanning of cell contents of secretory cavity characterized the presence of volatile oils presence of tannin. The volatile oils in leaves were highlighted in this schizogenous cavity in the parenchyma of the midrib (Figure $2 \mathrm{H}$ ). The tests used in the detection of alkaloids and condensed tanins returned negative results.

\section{DISCUSSION/ CONCLUSION}

\section{Anatomical analysis}

An adaptation of plants to high sunlight environments can be observed by decreased sinuosity of their cell walls as an alternative way to prevent excessive loss of water. ${ }^{22}$ This fact can be observed in targeted cells facing to the adaxial surface of Spondias mombin where the little sinuosity of their epidermal cells can be seen, a fact justified because it presents a predominant distribution in places of intense light radiation..$^{33}$ This feature can also be observed in S. tuberosa and S. dulcis. ${ }^{34,35}$

The results obtained in relation to stomatal type and distribution showed a hypostomatic leaf blade. Similar characteristics as the pattern of distribution and types of stomata were observed by Silva et al, ${ }^{34}$ when analyzing leaves of Spondias tuberosa. The presence of stomata anomocytic was also described by Chisom et $a^{36}$ when analysing Anacardium occidentale and $S$. mombin leaves. Santos et $a l^{35}$ also reported a leaf blade with the same distribution pattern of $S$. dulcis. The presence of such stomata is defined by Metcalf and Chalck ${ }^{37}$ as a standard for the Anacardiaceae family, present in Spondias species.

The presence of trichomes on both sides of the leaf, as observed in $S$. mombin, is very important because it creates a microenvironment rich in water vapor around the leaf, thereby helping to prevent excessive loss of water. ${ }^{38}$ Similar features were found by Silva et al ${ }^{34}$ who reported the presence of simple tector trichomes on both sides of the leaf of $S$. tuberosa, whereas this type of trichomes is a common feature found in species of this family. ${ }^{37}$ Descriptions made by Mitchell and Daly ${ }^{3}$ that realized a review of the species belonging to this genus, point to two types of trichomes, short and long thin forms. In contrast, the results of this study show the presence of uniseriate, unicellular, short trichomes.

Anatomical analysis indicates a dorsiventral mesophyll with two layers of palisade parenchyma in S. mombin. Different results were obtained to species from the same genera, as $S$. dulcis ${ }^{35}$ and $S$. tuberos $a^{34}$ for example, where the mesophyll only has an unistratified palisade parenchyma. However, the presence of a double layer parenchyma can also be observed in other species belonging to the Anacardiaceae family, as seen in Anacardium humile and Anacardium occidentale. ${ }^{39}$ The greater thickness of the exposed leaves to sunny region reflected an increase in the number of palisade layers from one to two, as observed in S. purpurea, resulting from the sun versus shade variables that the species is exposed. ${ }^{40}$

Regarding the midrib plane of symmetry and vascular organization of the central rib, the results support the analyzes made by Royo et al, ${ }^{39}$ where the existence of convex central rib with vascular bundle system side closed type was observed. Silva et $a l^{34}$ also reported the presence of collateral vascular bundles in closed arc disposition, seen in Spondias tuberosa leaves.

Corroborating the results obtained in this work, there is a presence of angular collenchyma in Anacardium occidenntale and A. humile on the abaxial surface of the midrib. ${ }^{39}$ Similar features were observed in stem of Spondias dulcis. ${ }^{41}$ Silva et al. ${ }^{34}$ reported the presence of angular chollenchyma in the adaxial surface, and angular type tending to lamellar in the abaxial surface in Spondias tuberosa leaflets.

According to Metcalfe \& Chalk ${ }^{37}$ and Cronquist, ${ }^{42}$ the presence of secretory structures is a common feature for members of the Anacardiaceae family, where the presence of secreting latex resiniferous channels or ducts can be checked and usually associated with the phloem. The results corroborate the studies by Silva et $a l,{ }^{43}$ where the schizogenous resiniferous cavities were observed in cortical parenchyma of Spondias tuberosa leaves. Ducts associated with vascular tissue have been described in the stem $^{44}$ and the leaf of Spondias dulcis, ${ }^{45}$ in the S. pinnata leaf ${ }^{46}$ and in the stem of other species of Anacardiaceae such as Anacardium spruceanum, ${ }^{47}$ Lithraea molleoides ${ }^{48}$ Schinus terebinthifolius and Mangifera indica. ${ }^{44}$

The presence of calcium oxalate crystals was described by Cronquist ${ }^{42}$ as a characteristic within individuals that belong to this family. Unlike Silva and Paiva ${ }^{34}$ who reported a greater incidence of crystals in the midrib region of $S$. tuberosa leaves. The presence of idioblasts containing such inclusions was observed in S. mombin, distributed throughout the mesophyll and midrib. According Metcalfe \& Chalk ${ }^{37}$ the presence of crystalline inclusions in plant leaves can be associated with an adaptive mechanism for greater capture of light and optimize the photosynthesis rate.

In studies conducted by Azevedo and contributors, ${ }^{49}$ characteristics similar to petiolule anatomy of S. mombin were found in the petiole of Schinus terebinthifolius (Anacardiaceae) as vascular bundles with collateral arrangement and the presence of secretory cavities well developed, generally associated to the phloem. The lumen of the ducts located in the phloem is also oval in cross section in young stems of Anacardium occidentale. ${ }^{39}$ These characteristics corroborate the study by Santos et al. ${ }^{41}$ which indicates the presence of secretory cavities in S. dulcis and as well as in S. tuberosa leaves. ${ }^{34}$

\section{Phytochemical prospection}

The phytochemical profile of native species becomes an important chemotaxonomic feature to be used as a tool in the standardization of plant raw material, besides being a lever in the search for new sources of bioactive molecules. ${ }^{50,51}$

According to the results of phytochemical in Spondias mombin, there is the presence of terpene origin of substances in the extract obtained from the leaves. Moronkola et al. ${ }^{52}$ reported more than 54 components in the essential oil composition of S. mombin, and caryophyllene the major compound hence corroborating the findings. In previously analyses, Lemos and contributors ${ }^{53}$ also found the presence of this group of compounds in leaves of different species of this genus. Terpene source substances, such as anacardic acid and caryophyllene, are responsible for the antimicrobial activity inhibiting B-lactamase. ${ }^{54,55}$ An isolated 
Vasconcelos, AL et al.: Pharmacognostic Characterization of Spondias mombin L.

triterpene from the methanol extract of the leaves, the $3-\beta$-urs-12-in3 -yl (9 z) hexadec-9-enoate, was assigned to hypoglycemic activity. ${ }^{56}$

By analysing the leaves of this species, Corthout and et al ${ }^{57}$ identified the presence of two ellagitannins, which was attributed to antiviral activity, effective against dengue type 2 . Several other authors also corroborate the results found in the analysis performed in this study, stating the presence hydrolyzable tannins. ${ }^{19,58,59,60,61}$

The tests also reveal the presence of cinnamic derivatives, flavonoids and phenylpropanoid glycosides. Studies by Corth out and colleagues ${ }^{62}$ demonstrate the antiviral action of the S. mombin, attributed to the presence of cinnamic derivatives and isolated phenylpropanoid. Preliminary data suggest that this phenolic acid in Spondias mombin is responsible for the antibacterial action and molluscicide of plant extract. ${ }^{63}$

Although a few researches have specifically targeted the flavonoids in this species, different authors mention the presence of this group. ${ }^{21,61,63,64,65}$

\section{Histochemical Analysis}

Histochemical analysis showed the presence of starch granules in the mesophyll, in the palisade parenchyma as well as in the spongy one. Starch grains are stored in the chloroplast and are important in all plants during periods when photosynthesis is not occurring, and after cellulose, the most abundant component processed by the plant cell. ${ }^{37} \mathrm{~A}$ common feature of some species of this family, as Spondias tuberosa, which has starch grains in collenchymatic and parenchymatic tissue of mesophyll. ${ }^{43}$ Fatty compounds found in the cuticle, facing to both leaf surfaces, and the presence of lignin were observed in the region of vascular bundles and sclerenchyma midrib. Reis et al ${ }^{66}$ showed the presence of lignins in the wall of xylem cells in histochemical assays of Anacardium occidentale. Almeida ${ }^{67}$ also reports the presence of lignin in xylem fibres of midrib and fibres in the mesophyll of leaflets Schinus terebinthifolius Raddi.

The histochemical tests revealed phenolic compounds contained in the palisade parenchyma in leaflet mesophyll region, within some of the epidermal cells and parenchyma of the midrib likewise observed in species of the same family, such as Spondias tuberosa Arruda and Schinus terebinthifolius in work carried out by Almeida, ${ }^{67}$ Kuklinski $^{68}$ and Cunha et al..$^{69}$

Reiterating the results obtained on chemical analysis, reactions with the reagent NADI revealed the presence of essential oils in the secretory cavities of the parenchymal midrib. The presence of essential oils in Anacardiaceae species was reported, with emphasis on their antimicrobial properties. ${ }^{70}$ When conducting studies of $S$. mombin leaves, Moronkola et $a .^{52}$ found the presence of different components in the essential oil composition, and $\beta$-caryophyllene was the major compound.

Crystalline inclusions of druses were observed in the perivascular regions, near the sclerenchyma. The reaction with hydrochloric acid showed the soluble nature of these inclusions, confirming the chemical composition of these calcium oxalate crystals. The presence of these inclusions, and the form they take in plants, can help in the characterization of taxonomic groups, making it relevant in the identification of herbal drugs. ${ }^{37}$ Mitchell and Daly ${ }^{3}$ report the presence of crystals in Spondias genera. In addition to calcium deposit, idioblasts can be formed by the accumulation of non usable substances by the plant, as protection or even as a mechanical support. ${ }^{37,71}$ According to Cronquist ${ }^{42}$ and Smith et $\mathrm{al}^{3,4,43}$ calcium oxalate crystals in the form of druses can be observed in xylem tissue, spongy mesophyll and more frequently in the midrib, leaves in S. tuberosa.

As can be seen, Spondias mombin L. is a species that has different popular uses and proven pharmacological activities. The results allowed to characterize anatomically the leaves of this species, outline a profile of its phytochemical constituents and, in addition, determine which anatomical structures of storage of these metabolites by the plant. The lack of studies to provide data about the pharmacognostic characteristics of the leaves of this species proves the importance of these results. Regarding both histochemical and phytochemical similarities, as well as the anatomical characteristics of the plant parts analysed, it is suggested that S. mombin is a promising native plant drug, whereas should be considered most depth pharmacological studies.

\section{ACKNOWLEDGEMENTS}

The authors thanks to Centro de Tecnologias Estratégicas do Nordeste (CETENE) for the valuable work on the electron microscopy slides preparation; an acknowledgment is also due to Herbário Dárdano de Andrade Lima for the botanical identification. Thanks to CNPQ for research funding.

\section{CONFLICT OF INTERET}

The authors have no conflict of interest to declare.

\section{REFERENCES}

1. Duvall CS. On the origin of the tree Spondias mombin in Africa. J Hist Geogr. 2006;32(2):249-66. http://dx.doi.org/10.1016/j.jhg.2005.02.001

2. Silva CLL, Pirani JR. Anacardiaceae. In:Forzza RC et al. Catálogo de plantas e fungos do Brasil. Rio de Janeiro: Jardim Botânico do Rio de Janeiro. 2010;599 602. PMCid:PMC2898542

3. Mitchell JD, Daly DC. A revision of Spondias L. (Anacardiaceae) in the Neotropics. PhytoKeys. 2015;55(1):1-92. http://dx.doi.org/10.3897/phytokeys.55.8489; PMid:26312044 PMCid:PMC4547026

4. Magalhães MA. Diversidade Genética em Taperebazeiro (Spondias mombin L., Anacardiaceae. M. Dissertation, Universidade Federal do Amazonas, Manaus, Brazil.( 2013)

5. Sacramento CK, Souza FX. Cajá (Spondias mombin L.). Série frutas Nativas (4) Rio de Janeiro: Funep; 2000. p. 42.

6. Pinto WS, Dantas ACVL, Fonseca AAO, Ledo CAS, Jesus SC, Calafange PLP, et al. Caracterização física, físico-química e química de frutos de genótipos de cajazeiras. Pesqui Agropec Bras. 2003;38( 9):1059-66.

7. Matos FKA. Plantas Medicinais: Guia de seleção e emprego das plantas usadas em fitoterapia no Nordeste do Brasil. $3^{\text {ed }}$. Fortaleza: Imprensa Universitária; 2007. p.394.

8. Miller AJ, Schaal B. Domestication of a Mesoamerican cultivated fruit tree, Spondias purpurea. Proc Natl Acad Sci. 2005;102(36):12801-6. http://dx.doi. org/10.1073/pnas.0505447102 ; PMid:16126899 PMCid:PMC1200284

9. Morton JF. Atlas of Medicinal Plants of Middle America. Bahamas to Yucatán: Charles C. Thomas, Springfield; 1981.

10. Lim TK. Edible Medicinal and Non-Medicinal Plants, Vol. I. Fruits. Netherlands: Springer; 2012.

11. Santana FF. Caracterização de genótipos de cajazeiras. D. Thesis, Faculdade de Ciências Agrárias e Veterinária, Universidade Estadual Paulista. São Paulo, Brasil. (2010).

12. Uchendu CN, Choudhary MI. The in vitro effects of butanolic leaf extract of Spondias mombin on rat uterine muscle. Nig J Exptl Appl Biol. 2004;5(1):10913.

13. Ademolal O, Fagbemi BO, Idowu SO. Anthelmintic activity of extracts of Spondias mombin against gastrointestinal nematodes of sheep: studies in vitro and in vivo. Trop Anim Health Prod. 2005;37(3):223-35. http://dx.doi.org/10.1023/ B:TROP.0000049296.47350.80

14. Olugbuyiro JAO, Moody JO, Hamann MT. AntiMtb activity of triterpenoidrich fractions from Spondias mombin L. African Journal of Biotechnology. 2009;8(9):1807-9.

15. Gomes MR, Rogero MM, Tirapegui J. Considerações sobre cromo, insulina e exercício físico. Revista Brasileira de Medicina do Esporte. 2005;11(5):262-6.

16. Ayoola PB, Adeyeye A, Onawumi OO. Trace elements and major minerals evaluation of Spondias mombin, Vernonia amygdalina and Momordica charantia leaves. Pakistan Journal of Nutrition. 2010;9(8):755-8. http://dx.doi.org/10.3923/ pjn.2010.755.758

17. Silva ARA, Morais SM, Marques MMM. Antiviral activities of extracts and phenolic components of two Spondias species against dengue virus. The Journal of Venomous Animals and Toxins Including Tropical Diseases. 2011;17(4):406-13

18. Accioly MP, Bevilaqua CM,Rondon FC, Morais SM, Machado LK, Almeida CA Leishmanicidal activity in vitro of Musa paradisiaca L. and Spondias mombin L. fractions. Vet Parasitol. 2012;187(1):79-84. http://dx.doi.org/10.1016/j.vetpar. 2011.12.029; PMid:22521971

19. Abo KA, Ogunleye VO, Ashidi JS. Antimicrobial Potential of Spondias mombin, Croton zambesicus and Zygotritonia crocea. Phytotherapy 
Vasconcelos, AL et al.: Pharmacognostic Characterization of Spondias mombin L.

Research. 1999;13(16):494-7. http://dx.doi.org/10.1002/(SICI)1099-1573(199909) 13:6<494::AID-PTR490>3.0.CO;2-9

20. Asuquo OR, Fischer CE, Mesembe OE, Igiri AO, Ekom JI. Comparative Study of aqueous and ethanolic leaf extracts of Spondias mombin on neurobehaviour in male rats. Journal of Pharmacy and Biological Sciences. 2013;5(2):29- 35. http:// dx.doi.org/10.9790/3008-0522935

21. Caraballo A, Caraballo B, Rodriguez AA. Preliminary assessment of medicinal plants used as antimalarials in the South-Eastern Venezuelan Amazon. Rev Soc Bras Med Trop. 2004;37(2):186-8. http://dx.doi.org/10.1590/S003786822004000200016 ; PMid:15094909

22. Budel JM, Duarte MR, Santos CAM, Farago PV, Matzenbacher NI. O progresso da pesquisa sobre o gênero Baccharis, Asteraceae: I- Estudos botânicos. Brazilian Journal of Pharmacognosy. 2005; 15: 268-71. http://dx.doi.org/10.1590/ s0102-695x2005000300018

23. Farias MR. et al. "Avaliação da qualidade de matérias-primas vegetais. In." Farmacognosia: da planta ao medicamento. 5ed. Porto Alegre/Florianópolis: UFRGS/UFSC; 2003;5:262-88.

24. Johansen DA. Plant microtechnique. New York: MacGraw-Hill Book Company; 1940.

25. Kraus JE, Arduin M. Manual básico de métodos em morfologia vegetal. Seropédica: Editora da Universidade Federal Rural do Rio de Janeiro;1997. p. 198.

26. Wagner H, Bladt S. Plant Drug Analysis: A thin layer chromatography atlas. Berlim: Spinger-Verlag; 1996.

27. Harborne JB. Phytochemical Methods. $3^{\text {ed }}$. London: Chapman \& Hall, 1998.

28. David R, Carde JP. Coloration différentielle des inclusions lipidique et terpéniques des pseudophylles du pin maritime au moyen du réactif Nadi. C R Acad Sci Paris. 1964;258(4):1338-40.

29. Yoder LR, Mahlberg PG. Reactions of alkaloid and histochemical indicators in laticifers and specialized parenchyma cells of Catharanthus roseus (Apocynaceae). American Journal of Botany. 1976;63:1167-73. http://dx.doi. org/10.2307/2441734

30. Jensen WA. Botanical histochemistry: principles and practice. San Francisco: W.H. Freeman \& Co; 1962

31. Gabe M. Techniques histologiques. Paris: Masson \& Cie, 1968.

32. Mace ME, Howell CR. Histochemistry and identification of condensed tannin precursor in roots of cotton seedlings. Canadian Journal of Botany. 1974 52(11):2423-6. http://dx.doi.org/10.1139/b74-314

33. Lorenzi H, Bacher ML, Lacerda M, Sartori S. Frutas brasileiras e exóticas cultivadas (de consumo in natura). São Paulo: Instituto Plantarum de Estudos da Flora; 2006. p.672.

34. Silva ON, Paiva JGA. Estudos morfológicos e anatômicos em folhas adultas de Spondias tuberosa Arruda (Anacardiaceae Lindley). Boletín Latinoamericano y del Caribe de Plantas Medicinales y Aromáticas. 2007;6(2):36-43.

35. Santos BFS, Azevedo, AA, Silva LC, Oliva MA. Diagnostic and prognostic characteristics of phytotoxicity caused by fluoride on Spondias dulcis Forst. F. (Anacardiaceae). An Acad Bras Cienc. 2012;84(3):689-702. http://dx.doi.org/10.1590/ S0001-37652012005000048

36. Chisom IF, Chukwu ON, Okeke CU. A comparative foliar anatomical and morphological study on Anacardium occidentale L. and Spondias mombin L. International Journal of Herbal Medicine. 2014;2(2):150-3.

37. Metcalfe CR, Chalk L. Anatomy of dicotyledons. vol I. Estados Unidos da América: Clarendon Press.1950. p. 1500.

38. Pascholati SF, Leite B. Hospedeiro: mecanismo de resistência. In: Bergamin Filho A, Kimati H, Amorim L. Manual de fitopatologia: princípios e conceitos. 3.ed. São Paulo: Agronômica Ceres. 1995.p.417-453.

39. Royo VA, Simões MOM, Ribeiro LM, Oliveira DA, Aguiar MMR, Costa ER, Ferreira PRB. Anatomy, Histochemistry, and Antifungal Activity of Anacardium humile (Anacardiaceae) Leaf. Microscopy and Microanalysis. 2015;21(6):1549-61. http://dx.doi.org/10.1017/S1431927615015457 ; PMid:26586138

40. Barrios EP, Hernandez BCR. Phenology, growth, and response to light of Ciruela Mexicana (Spondias purpurea L., Anacardiaceae). Economic Botany. 2003;57(4):481-90. http://dx.doi.org/10.1663/0013-0001(2003)057[0481:PGART L]2.0.CO;2

41. Santos BFS, Thadeo M, Meira RMSA, Ascensão L. Anatomy and histochemistry of stem secretory structures of Spondias dulcis Forst. F. (Anacardiaceae). Revista Árvore. 2006;30(3):481-9. http://dx.doi.org/10.1590/S0100-67622006000300019

42. Cronquist A. An integrated system of classification of flowering plants. United States of America: Press New York. 1981. p. 1262.

43. Silva ON, Chinalia LA, Paiva JGA. Caracterização histoquímica dos folíolos de Spondias tuberosa Arruda (Anacardiaceae Lindl.). Caatinga. 2008;21(3):62-8.

44. Venning FD. The ontogeny of the laticiferous canals in the Anacardiaceae. American Journal of Botany. 1948;35:637-44. http://dx.doi.org/10.2307/ 2438062

45. Silva LCDA, Azevedo AA, Silva EAM, Olívia MA. Flúor em chuva simulada: sintomatologia e efeitos sobre a estrutura foliar e o crescimento de plantas arbóreas.
Revista Brasileira de Botânica. 2000;23(4):385-93. http://dx.doi.org/10.1590/ S0100-84042000000400004

46. Khatoon S. A comprehensive review on Spondias pinnata. International Journal of Asia Pacific Studies. 2015; 2(4).

47. Paula JE; Alves JLH. Anatomia de Anacardium spruceanum Bth, Ex Engl. (Anacardiaceae da Amazônia). Acta Amazônica. 1973;3:39-53.

48. Carmello SM, Machado SR, Gregório EA. Ultrastructural aspects of the secretory duct development in Lithraea molleoides (Vell.) Engl. (Anacardiaceae). Revista Brasileira de Botânica. 1995;18:95-103.

49. Azevedo CF, Quirino ZGM, Bruno RLA. Estudo farmacobotânico de partes aéreas vegetativas de aroeira-vermelha (Schinus terebinthifolius Raddi, Anacardiaceae). Revista Brasileira de Plantas Medicinais. 2015;17(1):26-35. http:// dx.doi.org/10.1590/1983-084X/11_090

50. Buckingham J. Dictionary of Natural Products. London: Chapman and Hall. 1993

51. Filho RB. Contribuição da fitoquímica para o desenvolvimento de um país emergente. Química Nova. 2010;33(1):229-39. http://dx.doi.org/10.1590/S010040422010000100040

52. Moronkola DO, Adeleke AK, Ekundayo O. Constituents of the Spondias mombin Linn and the comparison between its fruit and leaf essential oils. Journal of Essential Oil Bearing Plants. 2003;6(3):148-52. http://dx.doi.org/10.1080/0972060X.2003.10643343

53. Lemos TLG, Nogueira PCL, Alencar JW, Craveiro AA. Composition of the Leaf Oils of Four Spondias Species from Brazil. Journal of Essential Oil Research. 1995:7(5):561-3. http://dx.doi.org/10.1080/10412905.1995.9698588

54. Coates NJ, Gilpin ML, Gwynn MN, Lewis DE, Milner PH, Spear SR, et al SB-202742 a novel beta-lactamase inhibitor isolated from Spondias mombin J Nat Prod. 1994;57(5):654-7. http://dx.doi.org/10.1021/np50107a016; PMid: 8064298

55. Crestani L, Manica V, Chiaradia V, Puton BMS, Paroul N, Cansian RL. Caracterização química e atividade antibacteriana do óleo essencial de Erva-luísa (Aloysia triphylla (L'hér.) Britton). Revista Perspectiva. 2012;36(135):53-63.

56. Fred-Jaiyesimi $A$, Kio A, Richard W. $\alpha$-amylase inhibitory effect of $3 \beta$-olean12-en-3-yl (9 z) hexadec-9-enoate isolated from Spondias mombin leaf. Food Chemistry. 2009;116:285-8. http://dx.doi.org/10.1016/j.foodchem.2009.02.047

57. Corthout J, Pieters LA, Claeys M, Vanden Berghe DA, Vlietinck AJ. Antiviral ellagitannins from Spondias mombin. Phytochemistry. 1991;30(4):1129-30. http://dx.doi.org/10.1016/S0031-9422(00)95187-2

58. Onwuka CFI. Hydrocyanic acid contents of tropical browse and their influence on performance of goats. Food Chemistry. 1992;45:5-10. http://dx.doi. org/10.1016/0308-8146(92)90003-K

59. Apori SO, Castro FB, Shand WJ, Orskov ER. Chemical composition, in sacco degradation and in vitro gas production of some Ghanaian browse plants. Animal Feed Science and Technology. 1998;76(1,2):129-37.

60. Edeoga HO, Eriata DO. Alkaloid, tannin and saponin contents of some Nigerian medicinal plants. Journal of Medicinal and Aromatic Plant Sciences. $2001 ; 23(3): 344-9$

61. Ayoka AO, Akomolafe RO, Iwalewa EO, Akanmu MA, Ukponmwan OE. Sedative antiepileptic and antipsychotic effects of Spondias mombin L. (Anacardiacaea) in mice and rats. J Ethnopharmacol. 2006;103(2):166-75. http://dx.doi.org/ 10.1016/j.jep.2005.07.019 PMid:16188408

62. Corthout J, Pieters LA, Claeys M, Vanden Berghe DA, Viletinck AJ. Antiviral Caffeoyl; Esters from Spondias mombin. Phytochemistry. 1992:31(6):1979-81. http://dx.doi.org/10.1016/0031-9422(92)80344-E

63. Corthout J, Pieters LA, Claeys M, Vanden Berghe DA, Viletinck AJ. Antibacterial and molluscicidal phenolic acid from Spondias mombin. Planta Med. 1994;60(5):460-3. http://dx.doi.org/10.1055/s-2006-959532 ; PMid:7997478

64. Akubue PI, Mittal GC, Aguwa CN. Preliminary pharmacological study of some Nigerian medicinal plants. J Ethnopharmacol. 1983;8(1):53-63. http://dx.doi. org/10.1016/0378-8741(83)90089-2

65. Ayoka AO, Akomolafe RO, Iwalewa EO, Ukponmwan OE. Studies on the anxioIytic effects of Spondias mombin L. (Anacardicaea) extracts. African Journal of Traditional, Complementary and Alternative Medicine. 2005;2(2):153-65. http:// dx.doi.org/10.4314/ajtcam.v2i2.31113

66. Reis ALLE, Silva DS, Silva KLF, Chagas DB. Caracterização anatômica e histoquímica de raízes e folhas de plântulas de Anacardium occidentale L. (Anacardiaceae). Revista Árvore. 2014;38(2):209-219. http://dx.doi.org/10.1590/ S010067622014000200001

67. Almeida CCBR. Estudo farmacognóstico e validação de metodologia espectrofotométrica para quantificação de taninos nas cascas de Schinus trebinthifolius Raddi. Pharm. M. Dissertation, Universidade Federal de Pernambuco, Recife, Brasil. 2013

68. Kuklinski C. Farmacognosia: Estudio de lãs drogas y sustancias medicamentosas de origen natural. Barcelona: Ediciones Omega; 2000.p.515.

69. Cunha AP, Salgueiro L, Roque OR. Alcaloides - aspectos gerais, p. 485-493. In: Cunha AP. Farmacognosia e Fitoquímica. Lisboa: Fundação Calouste 
Vasconcelos, AL et al.: Pharmacognostic Characterization of Spondias mombin L.

Guilbenkian; 2005.p.670

70. Alma MH, Nitz S, Kollmannsberger H, Digrak M, Efe FT, Yilmaz N. Chemical composition and antimicrobial activity of the essential oils from the gum of Turkish Pistachio (Pistacia x vera L.). Journal of Agricultural and Food Chemistry.
2004;52(12):3911-4. http://dx.doi.org/10.1021/jf040014e ; PMid:15186116

71. Cutter EG. Anatomia Vegetal. Parte I: Células e Tecidos. $2^{a}$ ed. São Paulo: Roca; 1986. p. 670.

Cite this article : de Vasconcelos AL, de Vasconcelos AL, Randau1 KP. Pharmacognostic Characterization of Spondias mombin L.(Anacardiaceae). Pharmacognosy Journal. 2016;8(6):513-519. 